\title{
Large-scale partial melting of deeply subducted continental slab during continental collision: An example from the Sulu orogen
}

\author{
HE-ZHI MA ${ }^{1}$, YI-XIANG CHEN ${ }^{1,2}$, YONG-FEI ZHENG ${ }^{1,2}$
}

${ }^{1}$ CAS Key Laboratory of Crust-Mantle Materials and Environments, School of Earth and Space Sciences, University of Science and Technology of China, Hefei 230026, China

${ }^{2}$ CAS Center for Excellence in Comparative Planetology, USTC, Hefei 230026, China

Partial melting of deeply subducted continental slab during continental collision greatly affects the tectonic evolution of collisional orogens. However, it is difficult to constrain the detailed timing, P-T conditions and spatial distribution of such melting experienced by the high-grade metamorphic rocks. To address this issue, we carried out a combined study of whole-rock geochemistry, and zircon U$\mathrm{Pb}$ dating, $\mathrm{O}$ isotopes and trace element compositions for the granites in the Sulu orogen, China. Several granitic plutons of late Triassic age were firstly found in this typical collisional orogen, with a total area of $\sim 10 \mathrm{~km}^{2}$, which suggests a large scale partial melting of the deeply subducted continental slab during continental collision. Field observations along with microstructural observations of melt pseudomorphs in thin sections as well as the zircon REE patterns suggest that these rocks formed from granitic magmatism. The granites are high-K calc-alkaline and show enrichment in LILE and LREE but depletion in HFSE in trace element distribution patterns. Zircons in these samples contain relict magmatic core of middle Neoproterozoic age and magmatic overgrowth rims of late Triassic age (with a peak at $\sim 210 \mathrm{Ma}$ ) and low $\delta^{18} \mathrm{O}$ values ( $<4 \%$ ). These results suggest that they grew from granitic magma during early exhumation of the deeply subducted continental crust of Yangtze block. The coesite inclusion was firstly found in one anatectic zircon grain of one granite, indicating the deep origin of initial granitic melts with a depth of $>80 \mathrm{~km}$. The granites was probably formed by dehydration melting of hydrous minerals in the subducted continental crust during early exhumation. Therefore, the large-scale partial melting of deeply subducted continental slab was firstly reported in a typical continental collisional zone, which may have a great implication for the tectonic evolution of collisional orogens. 